\title{
Front Matter: Volume 6933
}

, "Front Matter: Volume 6933," Proc. SPIE 6933, Smart Sensor Phenomena, Technology, Networks, and Systems 2008, 693301 (28 April 2008); doi: 10.1117/12.800947

SPIE Event: SPIE Smart Structures and Materials + Nondestructive Evaluation and SPIE. Health Monitoring, 2008, San Diego, California, United States 


\title{
PROCEEDINGS OF SPIE
}

\section{Smart Sensor Phenomena, Technology, Networks, and Systems 2008}

\author{
Wolfgang Ecke \\ Kara J. Peters \\ Norbert G. Meyendorf \\ Editors \\ 10-12 March 2008 \\ San Diego, California, USA \\ Sponsored by \\ SPIE \\ Cosponsored by \\ American Society of Mechanical Engineers (USA) \\ Cooperating Organizations \\ Intelligent Materials Forum (Japan) \\ Jet Propulsion Laboratory (USA) \\ National Science Foundation (USA) \\ Published by \\ SPIE
}


The papers included in this volume were part of the technical conference cited on the cover and title page. Papers were selected and subject to review by the editors and conference program committee. Some conference presentations may not be available for publication. The papers published in these proceedings reflect the work and thoughts of the authors and are published herein as submitted. The publisher is not responsible for the validity of the information or for any outcomes resulting from reliance thereon.

Please use the following format to cite material from this book:

Author(s), "Title of Paper," in Smart Sensor Phenomena, Technology, Networks, and Systems 2008, edited by Wolfgang Ecke, Kara J. Peters, Norbert G. Meyendorf, Proceedings of SPIE Vol. 6933 (SPIE, Bellingham, WA, 2008) Article CID Number.

ISSN 0277-786X

ISBN 9780819471192

Published by

SPIE

P.O. Box 10, Bellingham, Washington $98227-0010$ USA

Telephone +1 3606763290 (Pacific Time) · Fax +1 3606471445

SPIE.org

Copyright (c) 2008, Society of Photo-Optical Instrumentation Engineers

Copying of material in this book for internal or personal use, or for the internal or personal use of specific clients, beyond the fair use provisions granted by the U.S. Copyright Law is authorized by SPIE subject to payment of copying fees. The Transactional Reporting Service base fee for this volume is $\$ 18.00$ per article (or portion thereof), which should be paid directly to the Copyright Clearance Center (CCC), 222 Rosewood Drive, Danvers, MA 01923. Payment may also be made electronically through CCC Online at copyright.com. Other copying for republication, resale, advertising or promotion, or any form of systematic or multiple reproduction of any material in this book is prohibited except with permission in writing from the publisher. The CCC fee code is 0277-786X/08/\$18.00.

Printed in the United States of America.

Publication of record for individual papers is online in the SPIE Digital Library.

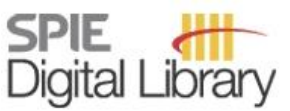

SPIEDigitalLibrary.org

Paper Numbering: Proceedings of SPIE follow an e-First publication model, with papers published first online and then in print and on CD-ROM. Papers are published as they are submitted and meet publication criteria. A unique, consistent, permanent citation identifier (CID) number is assigned to each article at the time of the first publication. Utilization of CIDs allows articles to be fully citable as soon they are published online, and connects the same identifier to all online, print, and electronic versions of the publication. SPIE uses a six-digit CID article numbering system in which:

- The first four digits correspond to the SPIE volume number.

- The last two digits indicate publication order within the volume using a Base 36 numbering system employing both numerals and letters. These two-number sets start with $00,01,02,03,04,05$, 06, 07, 08, 09, OA, OB ... 0Z, followed by 10-1Z, 20-2Z, etc.

The CID number appears on each page of the manuscript. The complete citation is used on the first page, and an abbreviated version on subsequent pages. Numbers in the index correspond to the last two digits of the six-digit CID number. 


\section{Contents}

ix Symposium Committee

xi Conference Committee

\section{SESSION 1 FIBER BRAGG GRATING SENSORS I}

693302 Fiber optic sensor-based SHM technologies for aerospace applications in Japan (Invited Paper) [6933-01]

N. Takeda, The Univ. of Tokyo (Japan)

693303 Effects of coating and diametric load on fiber Bragg gratings as cryogenic temperature sensors [6933-03]

M.-C. Wu, R. H. Pater, S. L. DeHaven, NASA Langley Research Ctr. (USA)

693304 Micro-size optical fibre strain interrogation system [6933-04]

N. Mrad, Defence R\&D Canada (Canada); G. Xiao, National Research Council (Canada);

H. Guo, Univ. of Ottawa (Canada)

\section{SESSION 2 FIBER BRAGG GRATING SENSORS II}

693307 Local strain measurement of Kevlar strand with fiber optic Bragg grating [6933-07]

C. E. Banks, J. Grant, S. Russell, NASA Marshall Space Flight Ctr. (USA); S. Arnett, TRI/Austin, Inc. (USA)

693308 Packaging of surface relief fiber Bragg gratings for harsh high temperature environments [6933-08]

J. D. Young, T. L. Lowder, R. H. Selfridge, S. M. Schultz, Brigham Young Univ. (USA)

\section{SESSION 3 HIGH-SPEED FBG SENSOR SYSTEMS}

693309 Fiber optic sensor networks in smart structures (Invited Paper) [6933-09]

H. Baier, U. C. Mueller, S. Rapp, Technische Univ. München (Germany)

6933 OA Improvement of FBG/PZT hybrid sensing system for composite materials [6933-10] S. Komatsuzaki, S. Kojima, A. Hongo, Hitachi Cable, Ltd. (Japan); N. Takeda, The Univ. of Tokyo (Japan); Y. Koshioka, R\&D Institute of Metals and Composites for Future Industries (Japan)

6933 OB Damage detection system with sub-microsecond resolution [6933-11]

E. Udd, Columbia Gorge Research, LLC (USA); J. Benterou, Lawrence Livermore National Lab. (USA)

6933 OC The use of fibre Bragg gratings to detect ultrasound in anisotropic materials [6933-12]

G. Thursby, B. Culshaw, Univ. of Strathclyde (United Kingdom); Y. Botsev, E. Arad, R. Zeyde, M. Tur, Tel-Aviv Univ. (Israel); I. Kressel, Israel Aircraft Industries (Israel) 
6933 OD Advanced FBG sensing through rapid spectral interrogation [6933-13]

W. Kunzler, J. Newman, D. Wilding, Z. Zhu, T. Lowder, R. Selfridge, S. Schultz, M. Wirthlin, Brigham Young Univ. (USA)

\section{SESSION 4 SENSOR SYSTEMS FOR MONITORING IN WIND ENERGY APPLICATIONS}

6933 OE Structural health monitoring of wind turbine blades (Invited Paper) [6933-14]

M. A. Rumsey, J. A. Paquette, Sandia National Labs. (USA)

$6933 \mathrm{OF} \quad$ Integrated monitoring of wind plant systems [6933-15]

M. J. Whelan, K. D. Janoyan, T. Qiu, Clarkson Univ. (USA)

\section{SESSION 5 FIBER OPTIC SENSORS IN ENERGY}

6933 OG The rising demand for energy: a potential for optical fiber sensors in the monitoring sector (Invited Paper) [6933-16]

T. Bosselmann, M. Willsch, Siemens AG (Germany); W. Ecke, IPHT Jena (Germany)

$6933 \mathrm{OH}$ On-line structural health and fire monitoring of a composite personal aircraft using an FBG sensing system (Invited Paper) [6933-17]

K. Chandler, Chandler Monitoring Systems Inc. (USA); S. Ferguson, T. Graver, A. Csipkes,

Micron Optics, Inc. (USA); A. Mendez, MCH Engineering, LLC (USA)

6933 Ol Fiber Bragg grating sensor system for operational load monitoring of wind turbine blades [6933-18]

W. Ecke, K. Schröder, IPHT Jena (Germany)

\section{SESSION $6 \quad$ WIRELESS SENSORS FOR SHM}

6933 0J Wireless vibration monitoring for damage detection of highway bridges (Invited Paper) [6933-19]

M. J. Whelan, M. V. Gangone, K. D. Janoyan, R. Jha, Clarkson Univ. (USA)

6933 OK Demonstration of a roving-host wireless sensor network for rapid assessment monitoring of structural health [6933-20]

D. D. L. Mascarenas, E. Flynn, K. Lin, Univ. of California, San Diego (USA); K. Farinholt, G. Park, Los Alamos National Lab. (USA); R. Gupta, M. Todd, Univ. of California, San Diego (USA); C. Farrar, Los Alamos National Lab. (USA)

$6933 \mathrm{OL}$ Field deployment of a dense wireless sensor network for condition assessment of a bridge superstructure [6933-21]

M. V. Gangone, M. J. Whelan, K. D. Janoyan, R. Jha, Clarkson Univ. (USA) 
693300 Strain measurement during stress rupture of composite over-wrapped pressure vessel with fiber Bragg gratings sensors [6933-24]

C. E. Banks, J. Grant, S. Russell, NASA Marshall Space Flight Ctr. (USA); S. Arnett, TRI/Austin, Inc. (USA)

6933 OP Research and development of impact damage detection system for airframe structures using optical fiber sensors [6933-25]

H. Tsutsui, N. Hirano, J. Kimoto, T. Akatsuka, H. Sashikuma, Kawasaki Heavy Industries, Ltd. (Japan); N. Takeda, The Univ. of Tokyo (Japan); N. Tajima, R\&D Institute of Metals and Composites for Future Industries (Japan)

6933 OR Chemical process monitoring and the detection of moisture ingress in composites [6933-28]

R. Mahendran, R. Chen, L. Wang, S. D. Pandita, V. R. Machavaram, S. N. Kukureka,

G. F. Fernando, Univ. of Birmingham (United Kingdom)

\section{SESSION 8 DISTRIBUTED SENSORS}

6933 OS Aircraft structural health monitoring using on-board BOCDA system [6933-29] T. Yari, K. Nagai, M. Ishioka, Mitsubishi Heavy Industries, Ltd. (Japan); K. Hotate, The Univ.of Tokyo (Japan); Y. Koshioka, R\&D Institute of Metals and Composites for Future Industries (Japan)

6933 OT A distributed fiber optic sensor system for dike monitoring using Brillouin optical frequency domain analysis [6933-30]

N. Nöther, A. Wosniok, K. Krebber, Federal Institute for Materials Research and Testing (Germany); E. Thiele, Saxon Textile Research Institute (Germany)

6933 OU Study on RC beams using BOTDA(R)-FRP-OF technique [6933-31]

J. He, Z. Zhou, Y. Huang, Harbin Institute of Technology (China); J. Ou, Harbin Institute of Technology (China) and Dalian Univ. of Technology (China)

\section{SESSION 9 POLYMER OPTICAL FIBER SENSORS}

6933 OV Smart technical textiles with integrated POF sensors (Invited Paper) [6933-32]

K. Krebber, P. Lenke, S. Liehr, J. Witt, M. Schukar, Federal Institute for Materials Research and Testing (Germany)

6933 OW Polymer in-fiber interferometer for large strain measurements (Invited Paper) [6933-33] S. Kiesel, K. Peters, T. Hassan, M. Kowalsky, North Carolina State Univ. (USA)

6933 OX Finite element formulation for self-writing of polymer optical fiber sensors [6933-34] A. D. Anderson, K. J. Peters, North Carolina State Univ. (USA) 
6933 OY POF strain sensor using phase measurement techniques (Invited Paper) [6933-35]

H. Poisel, Univ. of Applied Sciences Nuremberg (Germany)

$69330 Z$ Ultrasonic structural health monitoring: strategies, issues, and progress (Invited Paper) [6933-36]

J. E. Michaels, Georgia Institute of Technology (USA)

693310 Image-based monitoring of structural damage: concrete surface cracks [6933-37]

Z. Q. Chen, B. Chang, T. C. Hutchinson, Univ. of California, San Diego (USA)

SESSION 11 FIBER OPTIC SENSORS IN CIVIL ENGINEERING

693311 Applications of optical fiber sensors of SHM in infrastructures (Invited Paper) [6933-38]

J. Ou, Harbin Institute of Technology (China) and Dalian Univ. of Technology (China);

Z. Zhou, Harbin Institute of Technology (China)

693312 FBG based intelligent monitoring system of the Tianjin Yonghe Bridge [6933-39]

C. Lan, Z. Zhou, S. Sun, Harbin Institute of Technology (China); J. Ou, Harbin Institute of Technology (China) and Dalian Univ. of Technology (China)

693313 R\&D of smart FRP-OFBG-based steel strand and its application in monitoring of prestressing loss for RC [6933-42]

Z. Zhou, H. Zhou, Y. Huang, Harbin Institute of Technology (China); J. Ou, Harbin Institute of Technology (China) and Dalian Univ. of Technology (China)

693314 Torque sensing using rolled galfenol patches [6933-43]

M. J. Parsons, S. Datta, C. Mudivarthi, S. M. Na, A. Flatau, Univ. of Maryland, College Park (USA)

POSTER SESSION

693315 Landslide monitoring using a road-embedded optical fiber sensor [6933-44]

M. Iten, A. M. Puzrin, A. Schmid, Swiss Federal Institute of Technology (Switzerland)

693316 Health monitoring for subway station structure by fiber Bragg grating sensors [6933-45]

Y. Zhou, Y.-F. Wang, B. Han, Beijing Jiaotong Univ. (China); Z. Zhou, Harbin Institute of Technology (China)

693317 A novel multifunctional optical fiber sensor based on FBG and fiber optic coupler [6933-46] T. Fu, J. Fan, Harbin Institute of Technology (China); C. Wang, T. Liu, Shandong Academy of Science (China); J. Leng, Harbin Institute of Technology (China)

693318 Photonic crystal fiber long-period gratings for structural monitoring and chemical sensing [6933-47]

J.-L. Tang, National Chung Cheng Univ. (Taiwan); J.-N. Wang, National Yunlin Univ. of Science and Technology (Taiwan) 
693319 Development and application of 3D foot-shape measurement system under different loads [6933-48]

G. Liu, Beijing Institute of Machinery (China); B. Wang, H. Shi, X. Luo, Tsinghua Univ. (China)

6933 1B Comparison of the piezoelectric MEMS generators with interdigital electrodes and laminated electrodes [6933-50]

B.-S. Lee, S.-C. Lin, W.-J. Wu, National Taiwan Univ. (Taiwan)

Author Index 
Downloaded From: https://www.spiedigitallibrary.org/conference-proceedings-of-spie on 25 Apr 2023

Terms of Use: https://www.spiedigitallibrary.org/terms-of-use 


\title{
Symposium Committee
}

\author{
Symposium Chairs
}

Alison B. Flatau, University of Maryland, College Park (USA)

George Y. Baaklini, NASA Glenn Research Center (USA)

Donald J. Leo, Virginia Polytechnic Institute and State University (USA)

Kara J. Peters, North Carolina State University (USA)

Executive Committee

Alison B. Flatau, University of Maryland, College Park (USA)

George Y. Baaklini, NASA Glenn Research Center (USA)

Donald J. Leo, Virginia Polytechnic Institute and State University (USA)

Kara J. Peters, North Carolina State University (USA)

Mehdi Ahmadian, Virginia Polytechnic Institute and State University (USA)

Yoseph Bar-Cohen, Jet Propulsion Laboratory (USA)

Emilio P. Calius, Industrial Research Ltd. (New Zealand)

Marcelo J. Dapino, The Ohio State University (USA)

L. Porter Davis, Honeywell, Inc. (USA)

Michael A. Demetriou, Worcester Polytechnic Institute (USA)

Aaron A. Diaz, Pacific Northwest National Laboratory (USA)

Wolfgang Ecke, IPHT Jena (Germany)

Mehrdad N. Ghasemi-Nejhad, University of Hawai'i at Manoa (USA)

Victor Giurgiutiu, University of South Carolina (USA)

B. Kyle Henderson, Air Force Research Laboratory (USA)

Kumar V. Jata, Air Force Research Laboratory (USA)

Tribikram Kundu, The University of Arizona (USA)

Douglas K. Lindner, Virginia Polytechnic Institute and State University (USA)

Ajit K. Mal, University of California, Los Angeles (USA)

M. Brett McMickell, Honeywell, Inc. (USA)

Norbert G. Meyendorf, Fraunhofer-Institut für Zerstörungsfreie

Prüfverfahren (Germany) and University of Dayton (USA)

Zoubeida Ounaies, Texas A\&M University (USA)

Andrei M. Shkel, University of California, Irvine (USA)

Peter J. Shull, The Pennsylvania State University (USA)

Masayoshi Tomizuka, University of California, Berkeley (USA)

Vijay K. Varadan, University of Arkansas (USA)

Dietmar W. Vogel, Fraunhofer-Institut für Zuverlässigkeit und Mikrointegration (Germany)

H. Felix Wu, National Institute of Standards and Technology (USA)

Chung-Bang Yun, Korea Advanced Institute of Science and Technology

(South Korea) 
Downloaded From: https://www.spiedigitallibrary.org/conference-proceedings-of-spie on 25 Apr 2023

Terms of Use: https://www.spiedigitallibrary.org/terms-of-use 


\title{
Conference Committee
}

\author{
Conference Chair
}

Wolfgang Ecke, IPHT Jena (Germany)

\section{Conference Cochairs}

Kara J. Peters, North Carolina State University (USA)

Norbert G. Meyendorf, Fraunhofer-Institut für Zerstörungsfreie

Prüfverfahren (Germany) and University of Dayton (USA)

Program Committee

Grigory Adamovsky, NASA Glenn Research Center (USA)

Farhad Ansari, University of Illinois/Chicago (USA)

George Y. Baaklini, NASA Glenn Research Center (USA)

Horst J. Baier, Technische Universität München (Germany)

Xiaoyi Bao, University of Ottawa (Canada)

Hartmut Bartelt, IPHT Jena (Germany)

Axel Berthold, Fraunhofer-Institut für Zerstörungsfreie Prüfverfahren (Germany)

James L. Blackshire, Air Force Research Laboratory (USA)

Rolf Brönnimann, EMPA (Switzerland)

Richard O. Claus, Virginia Polytechnic Institute and State University (USA)

Brian Culshaw, University of Strathclyde (United Kingdom)

Richard D. Finlayson, Physical Acoustics Corporation (USA)

Gerald U. Gerlach, Technische Universität Dresden (Germany)

Joseph Grant, NASA Stennis Space Center (USA)

Wolfgang R. Habel, Bundesanstalt für Materialforschung und -prüfung (Germany)

Daniele Inaudi, Smartec SA (Switzerland)

Kerop D. Janoyan, Clarkson University (USA)

YeonWan Koh, FIBERPRO, Inc. (South Korea)

David A. Krohn, Light Wave Venture Consulting, LLC (USA)

Silvio Kruger, National Research Council Canada (Canada)

Jinsong Leng, Harbin Institute of Technology (China)

Alexis Méndez, MCH Engineering LLC (USA)

Bernd Michel, Fraunhofer-Institut für Zuverlässigkeit und Mikrointegration (Germany)

Jeff W. Miller, Micron Optics, Inc. (USA)

Marc Niklès, Omnisens S.A. (Switzerland)

Holger Speckmann, Airbus Deutschland GmbH (Germany) 
Nobuo Takeda, The University of Tokyo (Japan)

Roderick C. Tennyson, Fiber Optic Systems Technology, Inc. (Canada)

Michael D. Todd, University of California, San Diego (USA)

Eric Udd, Columbia Gorge Research, LLC (USA)

Zhishen Wu, Ibaraki University (Japan)

Chung-Bang Yun, Korea Advanced Institute of Science and Technology (South Korea)

Zhi Zhou, Harbin Institute of Technology (China)

\section{Session Chairs}

$1 \quad$ Fiber Bragg Grating Sensors I

Wolfgang Ecke, IPHT Jena (Germany)

Kara J. Peters, North Carolina State University (USA)

2 Fiber Bragg Grating Sensors II

Kara J. Peters, North Carolina State University (USA)

Wolfgang Ecke, IPHT Jena (Germany)

3 High-Speed FBG Sensor Systems

Alexis Méndez, MCH Engineering LLC (USA)

Michael D. Todd, University of California, San Diego (USA)

$4 \quad$ Sensor Systems for Monitoring in Wind Energy Applications

Jinsong Leng, Harbin Institute of Technology (China)

Don Snyder, Micron Optics, Inc. (USA)

$5 \quad$ Fiber Optic Sensors in Energy

Brian Culshaw, University of Strathclyde (United Kingdom)

Kerop D. Janoyan, Clarkson University (USA)

6 Wireless Sensors for SHM

Eric Udd, Columbia Gorge Research, LLC (USA)

Mark A. Rumsey, Sandia National Laboratories (USA)

$7 \quad$ Sensors for Structural Health Monitoring

Nobuo Takeda, The University of Tokyo (Japan)

Jinsong Leng, Harbin Institute of Technology (China)

8 Distributed Sensors

Hans Poisel, Georg-Simon-Ohm-Fachhochschule Nürnberg (Germany)

Daniele Inaudi, Smartec SA (Switzerland)

9 Polymer Optical Fiber Sensors

Horst J. Baier, Technische Universität München (Germany)

Jennifer E. Michaels, Georgia Institute of Technology (USA) 
10 Sensors for Nondestructive Evaluation

Wolfgang Ecke, IPHT Jena (Germany)

Matthew J. Whelan, Clarkson University (USA)

11 Fiber Optic Sensors in Civil Engineering

Katerina Krebber, Bundesanstalt für Materialforschung und -prüfung (Germany)

Joseph Grant, NASA Stennis Space Center (USA) 
Downloaded From: https://www.spiedigitallibrary.org/conference-proceedings-of-spie on 25 Apr 2023

Terms of Use: https://www.spiedigitallibrary.org/terms-of-use 